\title{
PENGARUH KEMAMPUAN APRESIASI PUISI TERHADAP KEMAMPUAN BERDEKLAMASI SISWA KELAS X SMA ST. ANTONIUS BANGUN MULIA MEDAN TAHUN AJARAN 2018/2019
}

\author{
Losten Tamba ${ }^{1}$, Maria Heprida Sibarani ${ }^{2}$ \\ ${ }^{1,2}$ Program Studi Pendidikan Bahasa dan Sastra Indonesia \\ Universitas Katholik Santo Tomas \\ Jalan Setia Budi, Nomor 479-F Tanjung Sari, Medan \\ Surel: ${ }^{1}$ lostentamba@gmail.com ${ }^{2}{ }^{2}$ mariaheprida.21@gmail.com
}

\begin{abstract}
ABSTRAK
Penelitian ini bertujuan untuk melihat pengaruh kemampuan apresiasi puisi terhadap kemampuan deklamasi siswa kelas X SMA St. Antonius Bangun Mulia Medan tahun ajaran 2018/2019. Pendekatan penelitian yang digunakan adalah kuantitatif dengan metode penelitian eksperimen. Objek dalam penelitian ini adalah siswa-siswi kelas X MIA dengan jumlah 27 orang. Instrumen pengumpulan data yang digunakan dalam penelitian ini adalah dengan menggunakan tes essai dan juga tes penampilan. Berdasarkan hasil perhitungan ditemukan bahwa rata-rata kelas X Mia pada penilaian kemampuan apresiasi adalah sebesar 74,07, standar deviasi sebesar 15,03 dan pada penilaian kemampuan deklamasi ditemukan rata-rata sebesar 80,11, serta standar deviasi sebesar 8,31. Uji hipotesis dicari dengan menggunakan rumus manual dengan taraf $\alpha=0,05$ dan perbandingan nilai $t_{\text {hitung }}, t_{\text {tabel }}$ dengan hasil perbadingan $t_{\text {hitung }}(5,415)>t_{\text {tabel }}(2,060)$ sehingga dapat disimpulkan bahwa ada pengaruh kemampuan apresiasi $(X)$ terhadap kemampuan deklamasi (Y) pada siswa kelas X MIA SMA St. Antonius Bangun Mulia Medan. Dengan persentase pengaruh yang ditimbulkan oleh kemampuan apresiasi adalah sebesar 40,80\% terhadap kemampuan deklamasi, maka dari itu kemampuan apresiasi berpengaruh positif terhadap kemampuan deklamasi.
\end{abstract}

Kata Kunci : Kemampuan apresiasi, deklamasi, puisi

\section{A. PENDAHULUAN}

Kemampuan deklamasi memiliki peran penting dalam perkembangan kemampuan siswa dalam menghargai karya sastra puisi, deklamasi itu sendiri berarti membacakan sebuah karya sastra dengan lagu atau gerak tubuh sebagai alat bantu gerak, yang dimaksud adalah gerak alat bantu puitis yang seirama dengan isi bacaan. Mendeklamasikan puisi bermakna membaca, tetapi membaca tidak sama dengan maksud mendeklamasi, maksudnya di sini bahwa apa pun pengertian membaca tetunya jauh berbeda dengan maksud deklamasi. Pengetahuan mengenai deklamasi ini lah yang kurang dikuasai oleh siswa selama ini yang ada dalam pola pikir siswa adalah bahwa deklamasi merupan sekedar membacakan puisi, tanpa ada tambahan hal lain dalam kegiatan membaca tersebut, berbanding terbalik dengan definisi deklamasi yang sesungguhnya. Mendeklamasikan sebuah puisi juga memiliki teknik 
tersendiri, teknik tersebut akan dijelaskan serinci mugkin dihadapan siswa, disertai dengan contoh yang tepat sehingga melalui penguasaan teknik tersebut akan peneliti temukan jawaban sejauh mana siswa mampu mendeklamsikan sebuah puisi.

Untuk lebih menghargai dan mencintai sebuah karya sastra puisi dibutuhkan sebuah kegiatan yang melibatkan para pembaca, pendengar atau pun penikmat puisi tersebut hal ini disebut dengan apresiasi, apresiasi pada puisi sendiri dimaksudkan untuk memberikan penilaian dengan menghayati, merasakan, mendalami isi dan makna puisi dengan menggunakan bahasa. Disick (Waluyo, 2005 :45) ada 4 tingkatan dalam mengapresiasi puisi yakni, Pertama tingkat menggemari jika siswa hanya baru sampai pada tingkat menggemari, bererati keterlibatan batinnya masih belum kuat, siswa hanya sebatas senang membaca puisi, menyediakan waktu apabila ada siaran mengenai puisi di acara tv, dan apabila ada lomba pembacaan ia turut memberikan waktu untuk melihat kegiatan tersebut. Kedua,tingkat menikmati pada tingkat ini keterlibatan batin siswa sudah semakin mendalam, dimana ketika siswa tersebut mendengar atau membaca sebuah puisi ia akan ikut sedih, terharu, bahagia, sesuai dengan perasaan yang disampaikan dalam puisi. Ketiga,mereaksi pada tingkat ini sikap kristis siswa terhadap puisi akan lebih menonjol karena ia telah mampu menafsirkan dengan seksama dan mampu menilai baik buruknya sebuah puisi. Keempattingkat produktif pada tingkat ini siswa mampu menghasilkan, menghasilkan bukan hanya sekedar mampu menuliskan atau menciptakan sebuah puisi melaiankan juga mampu mengkritik, mendeklamsi, atau membuat resensi terhadap sebuah puisi secara tertulis dengan kata lain, ada tindakan yang dihasilkan oleh siswa dengan pembelajaran apresiasi.

Kemampuan apresiasi inilah yang sulit ditemukan pada siswa, hal ini dapat dilihat dari keempat tingkatan di atas dimana secara keseluruhan siswa hanya memiliki kemampuan sebatas tingkat pertama dan kedua. Hal ini dikarenakan kurangnya kegiatan membaca puisi di sekolah, kemudian penggunaan teknik, model dan strategi pembelajaran yang monoton, yakni sebatas guru memberikan materi, kemudian memberikan contoh materi dan tugas, tanpa adanya pendalaman lebih lanjut mengenai materi puisi. Hal ini menyebabkan minat siswa terhadap mengapresiasi puisi semakin rendah. Supaya dapat mengapresiasi puisi, siswa memerluan pengenalan dan pengetahuan tentang puisi lebih khusus, dengan memberikan pembelajaran mengenai apresiasi puisi secara mendalam, juga dibarengi contoh dan tugas dibagian akhir proses pembelajaran. 


\section{B. KAJIAN TEORI}

Kemampuan berasal dari kata mampu yang mepunyai arti dapat atau bisa. Kemampuan juga juga disebut kompetensi. Kemampuan merupakan perubahan energi dalam diri seseorang yang ditandai dengan munculnya pikiran dan didahului dengantanggapan terhadap adanya tujuan. Sedangkan, apresiasi secara umum adalah suatu proses melihat, mendengar,mengahayati, menilai, menjiwai dan membandingkan atau menghargai suatu karya. Istilah apresiasi berasal dari bahasa latinapresiatif yang berarti mengindahkan atau menghargai. Selanjutnya apresiasi menurut gove (Aminuddin 2002:34) mengandung makna (1) pengenalan memalui perasaan atau kepekaan batin, (2) pemahaman dan pengakuan terhadap nilai-nilai keindahan yang diungkapkan pengarang.

Deklamasi berasal dari bahasa latin yang maksudnya declamare atau declaim yang mebawa makna membaca suatu hasil sastra yang berbentuk puisi dengan lagu atau gerak tubuh sebagai alat bantu Kemampuan deklamasi juga termasuk keterampilan aktif yaitu melahirkan pikiran dan perasaan sendiri dalam bentuk yang serasi dengan teliti dan terarah. Seorang dikatan mampu berdeklamasi apabilaia mampu melahirkan pikiran, perasaan dan kemampuan yang terkandung dalam juwa yang teratur, teliti, dan tepat secara lisan, sehingga orang dapat mengungkapkan sesuai dengan uyang dimaksud, Sugyanto (1981:1).

\section{METODE}

Metode penelitian merupakan cara pemecahan masalah penelitian yang dilaksanakan secara terencana dan cermat dengan maksud mendapatkan fakta dan kesimpulan agar dapat memahami, menjelaskan, meramalkan dan mengendalikan keadaan" Syamsuddin dan Damayanti (2011:14). Sunarti (2009:95) "Metode eksperimen merupakan metode penelitian yang menguji hipotesis berbentuk hubungan sebab-akibat melalui pemanipulasian variable independen dan menguji perubahan yang diakibatkan oleh pemanipulasian tersebut." Metode yang digunakan dalam penelitian ini adalah metode ekperimen. Untuk melihat pengaruh apresiasi puisi terhadap kemampuan siswa dalam mendeklamasikan puisi. 


\section{HASIL DAN PEMBAHASAN}

Wilayah studi penelitian ini berada di SMA St. Antonius Bangun Mulia Medan, tepatnya berada di Jln. Sisinga Mangaraja Km.11 Kecamatan Medan Amplas, Kelurahan Bangun Mulia. SMA St. Antonius Bangun Mulia Medan adalah salah satu dari beberapa sekolah swasta di Kecamatan Medan Amplas, didirikan pada 17 juni 1994. Dengan luas tanah $2.340 \mathrm{~m}^{2}$, jumlah ruangan kelas ada 7 ruangan, serta 4 ruang laboratorium, 1 ruang perpustakaan. Jumlah guru yang mengajar di SMA St. Antonius Bangun Mulia Medan adalah 13 guru dibantu oleh 3 pegawai. Dengan jenjang pendidikan pendidikan rata-rata S1, Kurikulum yang digunakan adalah kurikulum 2013 dan KTSP. Jumlah siswa seluruhnya 189 siswa yang terdiri dari 94 siswa laki-laki dan 96 siswa perempuan.

Pada penilaian ini melibatkan siswa secara keseluruhan, dimana untuk mengetahui kemampuan apresiasi seorang siswa dilakukan serangakaian tes yakni, tes esai. Yang dikerjakan siswa setelah peneliti memberikan materi dan contoh mengapresiasi sebelumnya. Setelah itu pada pertemuan selanjutnya di lakukan tes penampilan yang merupakan penampilan deklmasi. Peneliti menggunakan sebanyak 27 siswa sebagai sampel, yang terdiri dari satu kelas yakni kelas X MIA.

Kemampuan merupakan hal yang dimiliki oleh setiap siswa, Kemampuan pada dasarnya dapat diasah dan dipupuk baik oleh siswa sendiri maupun besama guru di sekolah. Peneliti berpikir bahwa kemampuan apresiasi maupun kemampuan deklamasi bisa dimiliki siswa apabila terlebih dahulu guru memupuk minat dan keinginan siswa untuk tahu lebih banyak hal-hal yang menarik dari sebuah puisi. Dimulai dari mengajak mereka untuk mengenali sejauh apa rasa tertarik mereka terhadap puisi untuk mengukur hal tersebut disick (Waluyo,2005:45) mengatakan ada 4 tingkatan dalam mengapresiasi yaitu :

1. Tingkat menggemari jika siswa hanya baru sampai pada tingkat menggemari, bererati keterlibatan batin nya masih belum kuat, siswa hanya sebatas senang membaca puisi, menyediakan waktu apabila ada siaran mengenai puisi di acara tv, dan apabila ada lomba pembacaan ia turut memberikan waktu untuk melihat kegiatan tersebut.

2. Tingkat menikmati pada tingkat ini keterlibatan batin siswa sudah semakin mendalam, dimana ketika siswa tersebut mendengar atau membaca sebuah puisi ia 
akan ikut sedih, terharu, bahagia, sesuai dengan perasaan yang disampaikan dalam puisi.

3. Tingkat Mereaksi pada tingkat ini sikap kristis siswa terhadap puisi akan lebih menonjol karena ia telah mampu menafsirkan dengan seksama dan mampu menilai baik buruknya sebuah puisi.

4. Tingkat produktif pada tingkat ini siswa mampu menghasilkan, menghasilkan bukan hanya sekedar mampu menuliskan atau menciptakan sebuah puisi melaiankan juga mampu mengkritik, mendeklamsi, atau membuat resensi terhadap sebuah puisi secara tertulis, ada tindakan yang dihasilkan oleh siswa dengan pembelajaran apresiasi.

Melalui keempat tingkat mengapresiasi tersebut akan ditemukan hal-hal yang merupakan poin penting dari kegiatan mengapresiasi, siswa akan lebih mudah menemukan tema, rasa (feeling), nada yang sesuai dengan perasaan yang tersirat dalam puisi, juga menyimpulkan hal positif apa atau amanat apa yang dapat dipetik dari isi puisi tersebut. Kemampuan berdekalamasi akan terpupuk pula apabila seseorang sudah menguasai hal-hal tersirat yang di sampaikan dalam sebuah puisi, tinggal bagaimana merealisasikannya melalui pelafalan, intonasi serta mimik yang tepat, ketiga hal ini akan mudah dilakukan saat berdeklamasi karena dasar dari berdeklamasi adalah mampu merasakan apa yang tertulis pada setiap bait puisi serta mampu menyapaikan kepada pendengar melaui nada, intonasi dan pelafalan yang jelas serta gerak mimik yang sesuai dengan perasaan yang terkandung pada tiap kata dalam puisi. Berikut ini adalah kemampuan siswa dalam Tes Apresiasi dan Tes Penampilan Deklamasi. 
Tabel 1 Daftar Nilai Tes Apresiasi dan Tes Penampilan Deklamasi

\begin{tabular}{|c|c|c|c|}
\hline No & Nama Siswa & Nilai Apresiasi & Nilai Deklamasi \\
\hline 1 & Afriani M. Barus & 70 & 65 \\
\hline 2 & Agnes M. Tarigan & 80 & 85 \\
\hline 3 & Ari N. Situmorang & 70 & 75 \\
\hline 4 & Carlos P. Panjaitan & 90 & 90 \\
\hline 5 & Della M. Tampublon & 95 & 95 \\
\hline 6 & Deni Asron Tamba & 40 & 80 \\
\hline 7 & Femi T. Tampubolom & 45 & 65 \\
\hline 8 & Fenny A. Siagian & 70 & 80 \\
\hline 9 & Joel K. Sidabutar & 60 & 70 \\
\hline 10 & Josua F. Lumbangaol & 80 & 85 \\
\hline 11 & Krisna K. Sitorus & 85 & 80 \\
\hline 12 & Marlina G. Munte & 85 & 85 \\
\hline 13 & Maysi S. Silaban & 75 & 80 \\
\hline 14 & Oby S. Sembiring & 75 & 90 \\
\hline 15 & Ocha Situmorang & 50 & 80 \\
\hline 16 & Sarma M. Gultom & 80 & 75 \\
\hline 17 & Siska Tamba & 65 & 75 \\
\hline 18 & Sri Afdelia Sitorus & 55 & 70 \\
\hline 19 & Sri Fitria Sitimorang & 80 & 80 \\
\hline 20 & Sri Monica Sebayang & 60 & 90 \\
\hline 21 & Suci Tiur Manihuruk & 100 & 95 \\
\hline 22 & Sherli Ginting & 75 & 75 \\
\hline 23 & Septa C. Ginting & 70 & 85 \\
\hline 24 & Septiani Sihombing & 100 & 95 \\
\hline 25 & Mawar A Sidabutar & 80 & 80 \\
\hline 26 & Markus Lubis & 80 & 80 \\
\hline 27 & Jerry M. Simarmata & 85 & 85 \\
\hline
\end{tabular}




\begin{tabular}{l|l|c|c}
\hline & Total & 2000 & 2190 \\
\hline & Rata-Rata & 74.07 & 80.11
\end{tabular}

Dari tabel di atas terlihat bahwa rata-rata kemampuan apresiasi siswa adalah 74,07 (kategori cukup) dan kemampuan mendeklamasikan siswa adalah 80.11 (kategori baik). Dengan distribusi sebagai berikut.

Tabel 2 Kemampuan Apresiasi Puisi

\begin{tabular}{c|c|c|c}
\hline Rentang Nilai & F. Absolut & F. Relatif & Kriteria \\
\hline $90-100$ & 4 & $15 \%$ & Sangat Baik \\
\hline $80-89$ & 9 & $33 \%$ & Baik \\
\hline $70-79$ & 7 & $26 \%$ & Cukup \\
\hline $60-69$ & 3 & $11 \%$ & Kurang \\
\hline$<60$ & 4 & $15 \%$ & Sangat Kurang \\
\hline & 27 & $100 \%$ & \\
& & &
\end{tabular}

Berdasarkan tabel di atas, dapat diketahui bahwa kemampuan apresiasi siswa terbagi dalam lima kategori, yaitu kategori sangat baik sebanyak 4 siswa atau 15\%, kategori baik sebanyak 8 siswa atau 33\%, kategori cukup sebanyak 7 siswa atau 26\%, kategori kurang sebanyak 3 siswa atau 11\% dan kataegori sangat kurang adalah 4 siswa atau sebanyak $15 \%$.

Tabel 3 Nilai Kemampuan Deklamasi

\begin{tabular}{c|c|c|c}
\hline Rentang Nilai & F. Absolut & F. Relatif & Kriteria \\
\hline $90-100$ & 6 & $22 \%$ & Sangat Baik \\
\hline $80-89$ & 12 & $45 \%$ & Baik \\
\hline $70-79$ & 6 & $22 \%$ & Cukup \\
\hline $60-69$ & 3 & $11 \%$ & Kurang \\
\hline$<60$ & 0 & 0 & Sangat Kurang \\
\hline & 27 & $100 \%$ & \\
& & &
\end{tabular}


Berdasarkan tabel di atas dapat diketahui bahwa kemampuan deklamasi siswa terbagi dalam 4 kategori yakni, siswa dengan nilai berkategori sangat baik yaitu sebanyak 6 siswa (22\%), siswa dengan nilai berkategori baik sebanyak 12 siswa (45\%), siswa dengan nilai berkategori cukup sebanyak 6 siswa (22\%), dan siswa dengan nilai kategori cukup sebanyak 3 orang ( $11 \%)$.

Penelitian ini dilakukan guna mengetahui ada tidaknya pengaruh atau akibat setelah adanya perlakuan kegiatan mengapresiasi, untuk melihat tingkat kemampuan deklamasi siswa. Hasil belajar yang diperoleh siswa dalam pembelajaran apresiasi puisi dan juga deklamasi memenuhi tingkat keberhasilan yang maksimal. Hal ini dapat dilihat berdasarkan nilai yang diperoleh siswa baik itu berupa tes esai dan juga tes penampilan .Pada test esai mengenai kemampuan apresiasi nilai siswa memiliki rata-rata 74,07 yakni sesuai dengan kriteria ketuntasan minimal, meskipun masih ada 9 dari 27 siswa yang masih memiliki nilai dibawah kriteria ketuntasan minimal.

Pada tabel 2 dan 3 diketahui bahwa nilai yang diperoleh siswa dari tes penampilan deklamasi puisi dengan rata-rata nilai sebesar 80,11, sementara kriteria ketuntasan minimal $(\mathrm{KKM})$ adalah 73. Uji hipotesis dicari dengan menggunakan rumus manual dengan taraf $\alpha=$ 0,05 dan perbandingan nilai $t_{\text {hitung }}, t_{\text {tabel }}$ dengan hasil perbadingan $t_{\text {hitung }}(5,415)>t_{\text {tabel }}(2,060)$ sehingga dapat disimpulkan bahwa ada pengaruh kemampuan apresiasi (X) terhadap kemampuan deklamasi (Y) pada siswa kelas X MIA SMA St. Antonius Bangun Mulia Medan. Dengan persentase pengaruh yang ditimbulkan oleh kemampuan apresiasi adalah sebesar 40,80\% terhadap kemampuan deklamasi, maka dari itu kemampuan apresiasi berpengaruh positif terhadap kemampuan deklamasi.

\section{E. KESIMPULAN}

Kemampuan apresiasi siswa Kelas X SMA St.Antonius Bangun Mulia Medan dengan pemberian materi yang mendalam serta contoh yang tepat dan merinci tentang mengapresiasi diperoleh rata-rata 74,07. Kemampuan apresiasi siswa terbagi dalam 5 kategori yakni, sebanyak 4 siswa yang memiliki nilai dengan kriteria sangat baik, 9 siswa berkategori baik, 7 siswa memiliki nilai kategori cukup, dan 3 orang siswa yang memiliki nilai dengan kategori kurang, serta 4 orang siswa yang memiliki nilai dengan kategori sangat kurang.Kemampuan deklamasi siswa Kelas X SMA St.Antonius Bangun Mulia Medan dengan nilai rata-rata 
80,11 terbagi dalam 4 kategori masing-masing terdapat 6 siswa yang memiliki nilai berkategori sangat baik, sebanyak 12 siswa yang memiliki nilai berkategori baik, 6 siswa memiliki nilai dengan kategori cukup, serta 3 siswa yang memiliki nilai dengan kategori kurang. Berdasarkan hasil analisis data terlihat bahwa ada pengaruh yang positif dari kemampuan apresiasi puisi siswa terhadap kemampuan deklamasi puisi siswa Kelas X SMA St.Antonius Bangun Mulia Medan sebesar 40,80 \%.

\section{F. SARAN}

Bagi peneliti lanjutan, diharapkan dapat mengembangkan hasil penelitian ini dalam ruang lingkup yang lebih luas serta menambah variabel lain yang lebih inovatif dan variatif dalam penelitian, sehingga dapat menambah wawasan untuk meningkatkan kualitas pendidikan, khususnya pembelajaran Bahasa Indonesia.

\section{DAFTAR PUSTAKA}

Aminuddin. 2014. Pengantar Apresiasi Karya Sastra. Bandung:CV. Sinar Baru Alegensindo.

Arikunto, Suharsimi. 2013. Metodelogi Penelitian. Yogyakarta: Bumi Aksara. 2017. Prosedur Penelitian Suatu Pendekatan Praktik. Jakarta: Rineka Cipta.

Arsjad, Maidar G dan Mukti U.S. 1988. Pembinaan Kemampuan Berbicara Bahasa Indonesi. Jakarta: Erlangga

Nurgiantoro, Burhan. 2012. Penilaian Pembelajaran Bahasa. Yogyakarta : Gadjah Mada University Press

Pradopo, Rachmat Djoko .2007. Beberapa Teori Sastra, Metode Kritik, dan Penerapannya. Yogyakarta: Pustaka Pelajar.

Ridwan. 2009. Metode \& Teknik Menyusun Proposal Penelitian. Jakarta: Alfabeta

Siswanto. 2008. Pengantar Teori Sastra. Jakarta: Grasindo

Subana. 2000. Statistik Pendidikan, Penerbit Pustaka Setia: Bandung

Sudjana. 2005. Metode Statistik. Bandung: Tarsito

2016. Penilaian Hasil Proses Belajar Mengajar. Bandung: Pt. Remaja Rosdakarya. Sugiyono. 2017. Metode Peneliitian Kuantitaif Kualitatif dan R\&D. Bandung: Alfabeta Sujono, Anas. 2010. Pengantar Statistik Pendidikan. Jakarta: PT. Raja Grafindo Persada. Sumarjono J, Saini K.M . 2013. Apresiasi Kesusastraan . Jakarta: Gramedia

Tusthi Eddy, Nyoman. 2009. Pengantar Singkat Keragaman dan Periodisasi Pembaharuan Puisi Indonesia. Ende-flores: Nusa Indah.

Waluyo Herman.J. 2014. Apresiasi Puisi. Jakarta: Gramedia.

Wellek \&Austin Warren ,2014. Teori Kesusastraan. Jakarta: Gramedia.

Diktat. 2016. Bahan ajar statistika. Fakultas keguruan dan Ilmu Pendidikan Universitas Katolik Santo Thomas Sumatera Utara. 